\title{
Incorporating novelty and novel ecosystems into restoration planning and practice in the 21 st century
}

\author{
Michael P Perring ${ }^{*}$, Rachel J Standish ${ }^{\dagger}$ and Richard J Hobbs
}

\begin{abstract}
Novelty pervades the biosphere. In some cases, potentially irreversible abiotic and/or biotic changes have led to the crossing of thresholds and thus the formation of "novel ecosystems." Their widespread emergence (particularly on land) and the presence of continued environmental change challenge a traditional restoration goal of restoring an historical ecosystem. Instead, we argue that restoration could broaden its frame of reference to consider how novel ecosystems might be used to maintain global biodiversity and provide ecosystem services and, in doing so, save potentially wasted efforts in attempting to fulfil traditional goals. Here we explore this contention in more depth by addressing: Are novel ecosystems innovative planning or lowering the bar? We show that novel ecosystems were not innovative planning in their original conception. On the contrary, they were recognized as ecosystems that were recalcitrant to traditional restoration approaches, coupled with an awareness that they had arisen inadvertently through deliberate human activity, either on- or off-site. Their recalcitrance to traditional restoration suggests that alternative goals may exist for these ecosystems using sometimes innovative intervention. This management may include biodiversity conservation or restoration for ecological function. We elucidate the latter aspect with reference to an experiment in the wheatbelt of Western Australia-The Ridgefield Multiple Ecosystem Services Experiment- the design of which has been informed by ecological theory and the acceptance of novelty as an ecosystem component. Although novel ecosystems do provide opportunities to broaden restoration planning and practice, and ultimately maintain and conserve global biodiversity in this era of environmental change, they necessarily "lower the bar" in restoration if the bar is considered to be the historical ecosystem. However, in these times of flux, such a bar is increasingly untenable. Instead, careful and appropriate interventions are required at local, regional, and global scales. These interventions need to take history into account, use ecological and evolutionary theory to inform their design, and be mindful of valid concerns such as hubris. Careful interventions thus provide an opportunity for broadening restoration's framework to focus on maintaining global biodiversity and delivering ecosystem services as well as the traditional goals of restoring historical ecosystems.
\end{abstract}

Keywords: No-analogue ecosystem; Biodiversity conservation; Ecosystem function; Ecological restoration; Restoration baseline; Ridgefield multiple ecosystem services experiment; York gum woodland

\footnotetext{
* Correspondence: michael.perring@uwa.edu.au

†Equal contributors

Ecosystem Restoration and Intervention Ecology Research Group, School of

Plant Biology, The University of Western Australia, 35 Stirling Highway,

Crawley, WA 6009, Australia
} 


\section{Introduction}

This Special Issue arose from a symposium at the Society for Ecological Restoration Australasia's inaugural conference, where the following question was posed:

"Are novel ecosystems innovative planning or lowering the bar for restoration and rehabilitation?"

We will explore this question by examining what we understand by the terms "novel ecosystem" and "novelty" and by arguing that novel ecosystems (as originally conceived) are not innovative planning. However, given their rising global prominence, we think they are a necessary consideration for restoration planning and practice in the 21st century. Such consideration exists in the broader context of what goals are appropriate for ecological restoration and for whom, in an ever-changing environment. Notably, the pervasiveness of environmental change questions the utility of traditional restoration goals, yet modifying goals can be perceived as "lowering the bar." At the same time, retaining strict fidelity to historical species composition as the basis for restoration goals in a time of environmental flux overlooks the chance that novel ecosystems may provide opportunities for biodiversity conservation and ecosystem service provision-not to mention potentially wastes scarce resources. In this era of novelty we discuss how other goals for restoration could be implemented for novel ecosystems. The management of novel ecosystems may be perceived as innovative given its departure from the way restoration has traditionally been approached and practiced. We conclude by suggesting firstly that novel ecosystems provide opportunities to broaden the framework of ecological restoration and contribute to biodiversity conservation in an era of global change, and secondly that the question of where and when to implement these opportunities needs careful consideration.

\section{Review}

\section{Novelty and novel ecosystems}

The global environment is changing as a result of the exponential increase in human activity since the start of the industrial era (Vitousek et al. 1997a,b; Ellis 2011). Species have responded idiosyncratically to these socioenvironmental changes (e.g., Lee and Caporn 1998; Tylianakis et al. 2008) by assembling and reassembling into communities. Given the pervasiveness of change, all ecosystems, whether on land or at sea, possess greater or lesser degrees of novelty, having no strict analogue in present or historic records (Halpern et al. 2008; Williams and Jackson 2007). Novelty per se does not limit the opportunities for restoration and conservation as traditionally practiced (Figure 1). In some instances, however, the scale of change has led to ecosystem states that are arguably not able to be returned, at least practically, to a desired former state due to the crossing of ecological and/ or socio-economic thresholds (Hobbs et al. 2009; Hallett et al. 2013). Ecosystems that have been identified as going beyond one or more of these alleged thresholds-the position and presence of which may differ depending on perspective-have been referred to as novel (Hobbs et al. 2006). Although the immediate actions of people were and continue to be deliberate, the consequences of such actions were not foreseen (or, at worst, lessons from previous development activities were deliberately ignored). Subsequently, novel ecosystems can be considered inadvertent consequences of deliberate human actions. Further, novel ecosystems exist both on- and off-site from the anthropogenic source of disturbance (e.g., abandoned agricultural fields vs. ecosystems with elevated nitrogen deposition) (Mascaro et al. 2013). As such, and in their original conception, we would argue that novel ecosystems are not innovative planning. They simply are: they do not arise through deliberate planning, innovative or otherwise. Instead, they can be summarized as being distinct from other ecosystems through having a difference in species composition, structure, or function. Secondly, they possess thresholds in these attributes at which change is irreversible, a potentially controversial designation. Lastly, novel ecosystems persist (i.e., are self-organizing) in the absence of continued human intervention (Harris et al. 2013) and have departed from their expected, historical trajectory. These characterizations provide the following working definition for novel ecosystems:

Novel ecosystems are a system of abiotic, biotic and social components (and their interactions) that, by virtue of human influence, differ from those that prevailed historically, having a tendency to selforganize and manifest novel qualities without intensive human management. Novel ecosystems are distinguished from hybrid ecosystems by practical limitations (a combination of ecological, environmental and social thresholds) on the recovery of historical qualities (Hobbs et al. 2013a).

\section{Whither restoration given the rising prominence of novel ecosystems?}

\section{The necessity of broadening the restoration framework}

Restoration ecologists have traditionally contemplated moving from an undesired ecosystem state to a desired state, where that desired state is usually one that existed historically (Hobbs and Norton 1996; SERI 2006). This basic (value-laden) tenet of restoration-i.e., that it is desirable to return to the historical reference-is increasingly questioned in an era of multiple, simultaneous, and rapid environmental changes. Indeed, recent meta-analyses have confirmed the sizeable gap between 


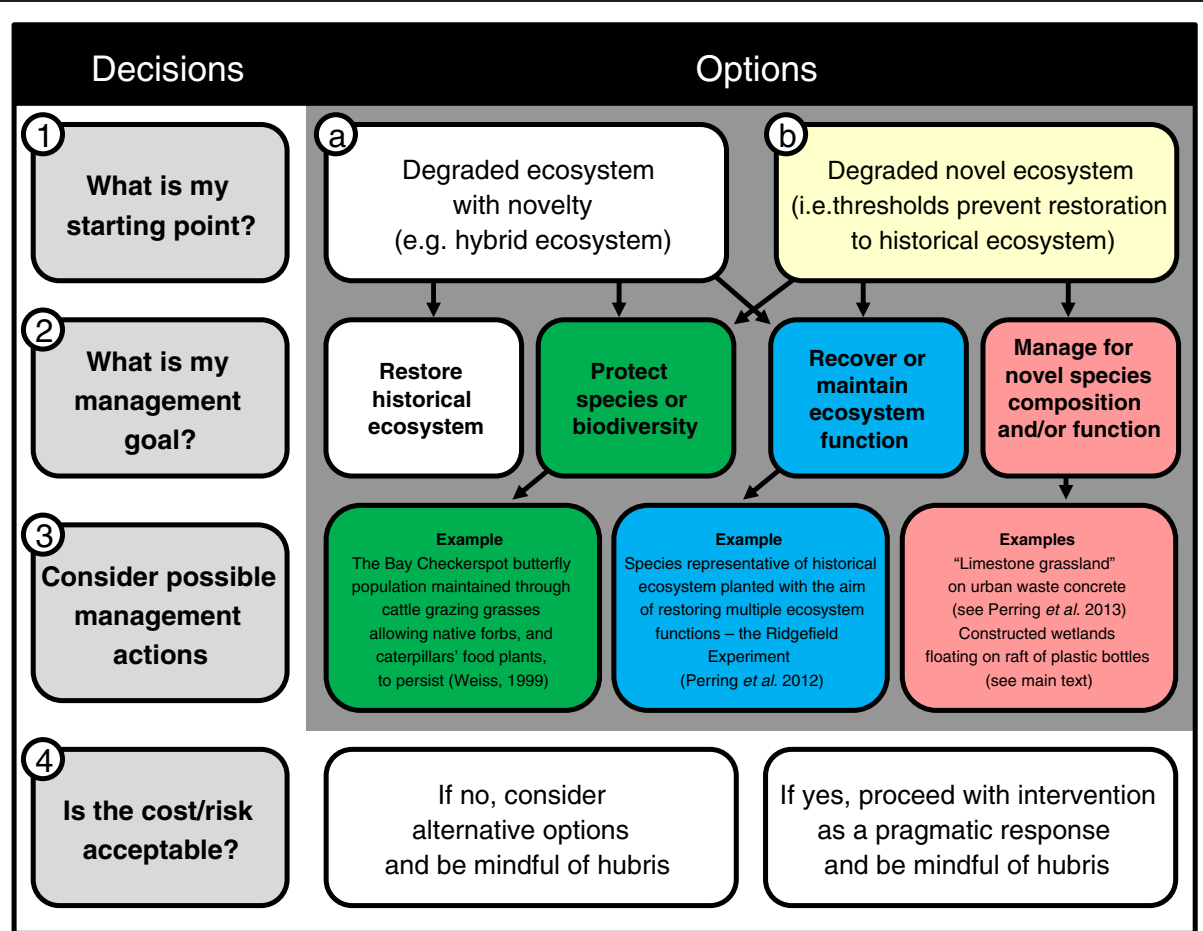

Figure 1 Management options for restoration where (a) novelty and (b) a novel ecosystem have been identified. Decisions need to be taken by working through questions 1-4 (left hand side); depending on your ecosystem's current condition, different goals are options for restoration management as further explored in the main text. Example management actions are provided for ecosystems identified as novel. This figure has been modified from Hulvey et al. 2013.

restored and reference ecosystems for projects with the latter as a goal (Rey-Benayas et al. 2009). Furthermore, going back to historic species compositions in a particular area may, in extremis, lead to local extinction if environmental conditions change sufficiently to alter conditions beyond species' niches [an "ossification" of the ecosystem (Harris et al. 2006)]. The identification of ecosystems as novel can therefore be useful in avoiding waste of scarce resources in potentially futile attempts to return to the historical reference state.

If novel ecosystems were rare across the biosphere, there may be little reason to consider them in restoration and conservation frameworks more broadly. However the pervasiveness of environmental change and human appropriation of natural resources suggests that this is an unlikely scenario. Indeed, recent global-scale estimates suggest between 35 and $40 \%$ of the terrestrial ice-free land surface may constitute novel ecosystems, with one estimate suggesting that novel ecosystems cover more land surface area than unused "wild" landscapes (Perring and Ellis 2013; Ellis et al. 2010).

Although such global-scale estimates of novelty clearly outline the necessity of considering novel ecosystems in restoration and rehabilitation, digging deeper into how estimates were calculated raises questions (Perring and Ellis 2013). Most importantly, estimates do not attempt to differentiate novel ecosystems from those that exhibit facets of novelty but are considered to be able to be returned to a reference state [termed "hybrid" systems by Hobbs et al. (2009) as noted in the definition]. Hobbs et al. (2013a) suggest that hybrid and novel ecosystems differ due to the crossing of thresholds such that abiotic or biotic changes are currently considered irreversible in novel ecosystems, for either ecological or socio-economic reasons. The identification of such thresholds remains an important constraint; arguably, virtually nothing is irreversible given enough input (e.g., Sherkow and Greely 2013). However, the recognition of limitations on restoration because of ecological change or socio-economic constraints is important for planning and setting priorities.

Notwithstanding the issues outlined above, the idea that novelty is pervading the biosphere is uncontroversial even if it is regretted by some. Indeed, it is expected that the novelty of ecosystems will increase over time (Jackson 2013). Given this increasing novelty, it is more likely that thresholds associated with irreversible change will be crossed, and novel ecosystems will therefore increase in prominence. Since novel ecosystems, by definition, resist traditional restoration efforts it would be tempting to ignore them, but the increasing prominence of novelty prompts us to consider what place novel 
ecosystems might have in restoration planning and practice. If novel ecosystems do have a place in restoration, can we set socially acceptable and innovative goals for their management? If so, are such goals lower than the bar set by traditional ecological restoration?

\section{Managing novel ecosystems: innovation in restoration planning and practice?}

Ecological restoration's basic tenets are under question in the context of rapidly changing environments. Restoring to historical ecosystems is unlikely to be a realistic or practical goal for novel ecosystems. We therefore need to consider how to amend the tenets of restoration while not losing sight of the broader goals of biodiversity conservation and the delivery of ecosystem services. We suggest that ecological restoration requires a broadening of its frame of reference in which historical ecosystem composition, and particularly function, inform planning but do not place strictures upon it. In short, we think there is a necessity for restoration policy, planning, and practice to take account of the presence of novel ecosystems. Restoration ecologists could pave the way for innovative management practices by using novel ecosystems as test beds for new ideas (Hobbs et al. 2013b). Ultimately, testing new ideas via research and restoration practice will inform the management of novel ecosystems.

This test-bed concept has been utilized in the design of an experiment in the wheatbelt of south-west Western Australia, where we (the authors) and others are investigating how compositional differences among restored assemblages of native species influence ecosystem function on degraded agricultural land (Perring et al. 2012). Habitat fragmentation and climate change, together with nonnative species and high nutrient levels, can prevent the recovery of historical ecosystems (e.g., Prober and Smith 2009; Pywell et al. 2007). Furthermore, old-fields that do not recover without assistance are likely to be resistant to traditional restoration efforts (Cramer et al. 2008). Given the presence of multiple, potentially irreversible changes, abandoned agricultural lands are therefore one of the places where novel ecosystems can develop (Hobbs et al. 2006).

At the experimental site, ecological and socio-economic thresholds are present which indicated that restoration to historic York gum woodland would likely be prevented (Standish et al. 2007). Chief among the changes that are difficult to reverse are missing soil seed banks, nutrient enrichment, the presence of competitive non-native species, and reduced seed sources and land degradation associated with habitat fragmentation (Standish et al. 2006, 2007, 2008). Socio-economically, there is not the current knowledge to recover all facets of the historic ecosystem (e.g., native ground cover), and additionally there is not the needed level of investment to discern methods to do so. We have also heard concerns from some farmers about widespread re-vegetation leading to increased fire risk as well as opportunity cost. Whether these changes are truly irreversible is hard to determine, but we assumed that without intervention the experimental site would constitute an unmanaged novel ecosystem now and into the future, particularly given the further context of the drying climate of the region (CSIRO 2007).

Where a novel ecosystem is identified and the restoration of the historic ecosystem is precluded, management options can broaden from those focused on the restoration of historical baselines (Figure 1). Other goals for novel ecosystems include biodiversity conservation (of one or multiple species) and the restoration of ecosystem functions (Low 2003; Hallett et al. 2013; Hulvey et al. 2013). In ecology, the meaning of "function" can relate to processes, such as efficient nutrient cycling and storage of carbon, or to the roles that particular species play, or may be applied to the system as a whole in terms of its "health" or otherwise (Jax 2005). Restoration of mined landscapes, for example, often aims to restore the abiotic processes that sustain ecosystem functions through the reconstruction of soils, slope, and landscape hydrology [i.e., rehabilitation (Bradshaw 1997)].

At the experimental site, we set goals focused on the provision of combinations of ecosystem functions and services through the restoration of elements of the historical ecosystem. We defined functions in terms of ecosystem processes and concentrated on how we might design restoration plantings to support such processes, particularly those valued by people, i.e., ecosystem services (Millennium Ecosystem Assessment 2005). Thus we developed the Ridgefield Multiple Ecosystem Services Experiment, which will include measurement of these services: carbon sequestration, invasion resistance to weeds, and reduction of excess soil nutrients to avoid eutrophication (Perring et al. 2012).

\section{The Ridgefield Multiple Ecosystem Services Experiment: a test bed for restoration of ecosystem functions in novel ecosystems}

We chose to plant native vegetation with different traits which we hypothesized would influence the provision of our targeted ecosystem services based on our knowledge of ecological theory (e.g., Hooper et al. 2005; Cardinale et al. 2012; McGill et al. 2006). Functional groups are defined by rooting depth at maturity and nutrient acquisition traits including whether plants form cluster-roots, fix nitrogen, and/or associate with arbuscular and ectomycorrhizal fungi (see also Table two in Perring et al. 2012). In addition to a gradient of species and functional richness, two experimentally manipulated environmental changes increase abiotic and biotic novelty. Nitrogen deposition is being simulated by the application of dry 
ammonium nitrate to mimic the projected maximum rate of nitrogen deposition in this area around 2050 (Phoenix et al. 2006). Non-native herbaceous species are being removed through the application of broad-spectrum herbicide (glyphosate) at least twice per year. With these manipulations we are asking whether the presence of a novel component (non-native weed species) in different environmental contexts (with and without nitrogen deposition) affects the delivery of ecosystem services. The restored systems also possess novelty on at least three counts compared with the reference York gum woodland: they are planted at greater density, lack a forb-rich native understory (Prober et al. 2011), and are (essentially) evenaged (Figure 2).

The managed novel ecosystem at Ridgefield may have a number of benefits consistent with the goals of traditional restoration. For instance, plots with greater plant biodiversity and more structural complexity will likely support more species than a simple mono-culture [e.g., birds (Munro et al. 2011)]. In addition, the planting forms a block of vegetation that links remnant patches of native vegetation. Thus available habitat has increased, which may be of particular importance to wildlife that requires large areas of habitat for foraging and survival. However, water relations could be negatively affected, which in turn may have indirect effects on biodiversity (Bradshaw et al. 2013). On the whole, we argue that deliberate intervention after agricultural abandonment, as outlined by reference to Ridgefield, is an innovative response towards ensuring the ongoing supply of ecosystem services and biodiversity conservation within the agricultural landscape. The ecosystem remains novel due to its component parts and underlying environmental changes (e.g., high soil nutrient levels), but it has historical echoes through the use of native canopy species that we chose based on an expectation that they would be somewhat adapted to the environmental conditions of the site. Ridgefield has become a test bed for exploring how to manage novel ecosystems that have emerged from abandoned agricultural land in a way that acknowledges the environmental changes of the 21st century. This test-bed concept could be extended to include how genetic provenance also influences the provision of ecosystem services in a changing environment (e.g., Whitham et al. 2008).

\section{Broadening restoration goals through novel ecosystems}

Deliberate creation of novel ecosystems, sometimes without historical precedent, may also have a place in achieving restoration goals more broadly, although context is important. For instance, urban ecosystems, remnants or otherwise, have vastly changed abiotic and biotic conditions compared to the ecosystems that occupied the landscape before urbanization (McDonnell and Pickett 1990; Paul and Meyer 2001; Pickett et al. 2001). Ongoing fragmentation and development superimposed on this changed palette make a restoration goal of returning to the historical reference somewhat moot (Perring et al. 2013). Instead, a pragmatic approach might be to manage urban ecosystems for multiple benefits. For example, floating wetlands made from rafts of plastic bottles have improved habitat quality in polluted waterways in Baltimore and elsewhere on the eastern seaboard of the United States. Not only has this project had water quality and habitat benefits, but it has also addressed social ills and made local youth in the area feel empowered (Keith Bowers 2012, pers. comm.).

We stress here that deliberate creation of a novel ecosystem as described above is, we think, a potentially pragmatic and innovative solution for the management of novel conditions that have arisen inadvertently. However, we do not mean to suggest that novel ecosystems be created in places where there is the potential to achieve goals akin to traditional restoration and conservation practices. Indeed, while the creation of novel ecosystems may be a sensible approach to ecosystem management in some cases, ecologists, restoration practitioners, and planners must be mindful of hubris or overestimating the ability to understand and manage complex ecosystems (Standish
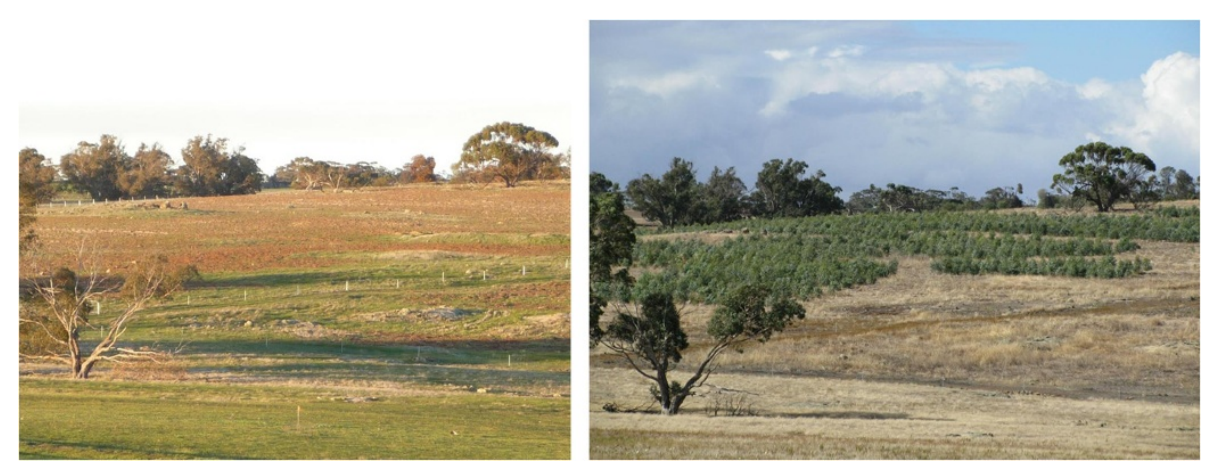

Figure 2 Ridgefield before (2 August 2010) and after (17 April 2012) planting to restore multiple functions. Photo credits: M.P. Perring (left) and Nancy A. Shackelford (right). 
et al. 2013). These points highlight again the need to establish metrics about when interventions may be sensible or otherwise, depending upon ecosystem state and landscape context (e.g., Kirkpatrick and Kiernan 2006).

\section{Accepting novel ecosystems: lowering the bar in restoration planning and practice?}

There are a number of concerns about the management of novel ecosystems, beyond hubris, that warrant discussion and provide a counterweight to the utilitarian arguments outlined above. Perhaps the most widely held concern is the sense that their incorporation into management frameworks could lead to a lowering of the bar for restoration practice, as made clear by the organizers of the Special Issue. The "bar" in this case is the historical ecosystem, the goal of restoration as traditionally practiced. The setting of the "bar" in reality depends upon the goals set for restoration-some defend the traditional notion of restoration and wish to restrict the term to activities that fit a relatively limited definition (e.g., Clewell and Aronson 2013), whereas others have argued that the traditional perspective is too narrow to encompass all the types of activity undertaken to achieve various types of environmental repair (Hobbs 2007; Suding 2011). Different goals will have different "bars." Hence the discussion of novel ecosystems is part of a broader debate on what restoration is or should be. If we accept that the historic ecosystem is an unobtainable, possibly unknowable, goal for novel ecosystems, then pragmatically a different goal must be set for their management. Accepting this fact will be difficult for some people, particularly if they are also concerned that the goals for the management of novel ecosystems are somehow less valuable than the historic ecosystem (Light et al. 2013). Such concerns place a premium on the proper diagnosis of a novel ecosystem (i.e., one where change has gone beyond a threshold, making it irreversible), although novelty, in the absence of thresholds, will likely have to be considered as restoration moves into the future. Additionally, the environmental virtues of those people involved in the decision-making process for the management of novel ecosystems are arguably more critical than they are for traditional restoration practice because there is more choice about the goal to set and how to achieve it (Light et al. 2013). The challenge that global environmental change brings to the practice of environmental management is not unique to novel ecosystems. Indeed, there is evidence to suggest that traditional conservation practice is also evolving to meet these challenges, with similar potential for controversy (e.g., assisted migration, cryo-preservation, seed banking).

The concern that people will exercise human ambition in the management of novel ecosystems is a valid one (Standish et al. 2013) and may be a persistent concern in that it is not readily argued away. On the other hand, some concerns about novel ecosystems are misapprehensions, including a belief that invasive species will be accepted, that acceptance of novel ecosystems will replace traditional conservation and restoration practices, and that our Western consumer culture lends itself to accepting novel ecosystems into management frameworks simply because they are "new." These misapprehensions can be argued away convincingly-invasive species, whether native or non-native, should still be tackled where they pose a threat-but measures of impact may provide a pragmatic approach where prevention has already failed (Shackelford et al. 2013). The management framework of novel ecosystems provides a broadening of traditional frameworks, not a replacement. Indeed, it is distinctly possible that history will become more important in restoration practice as it provides the cultural and moral guidance alluded to above (Eric Higgs 2012, pers. comm.). The pervasiveness of consumer culture and its valuation of new can be less readily argued away and so gives us pause to reflect and "places a premium on anticipating these patterns" (Standish et al. 2013).

\section{Conclusion}

Novelty across the biosphere is pervasive. In some cases, human-caused biotic and abiotic changes associated with intensive land use can result in the crossing of thresholds (ecological, economic, and/or social) which prevent the return of historical ecosystems and instead lead to the formation of novel ecosystems. Since environmental changes and human influence are here to stay for the foreseeable future, novel ecosystems, or novelty at the very least, must necessarily be considered in restoration planning and practice. We argue this requires the broadening of traditional conservation and restoration management frameworks to incorporate goals for the management of novel ecosystems. One alternative goal is to restore ecosystem services, and test beds are required to investigate ecologically and ethically sound ways of doing this (e.g., Ridgefield). Other management goals for novel ecosystems include conservation of desired species through the use of novel components or the creation of new ecosystems to achieve desired goals (Figure 1). Recognition of novel ecosystems may save wasted restoration effort and better direct scarce resources to help maintain the globe's unique biodiversity and the ecosystem services that are underpinned by it (Hallett et al. 2013). However, these contentions, and particularly the identification of thresholds beyond which change is irreversible, need to be empirically tested, with options weighed carefully in the balance. Ultimately, humanity needs to find ways to lessen its impact upon ecosystems to help prevent environmental 
degradation such that our unique global biodiversity, and the evolutionary processes that promote it, can be maintained.

\section{Competing interests}

The authors declared that they have no competing interests.

\section{Authors' contributions}

MPP conceived of and wrote the paper with RJS making an equally substantial contribution. RJH commented on previous drafts and guided the development of the manuscript. All authors read and approved the final version.

\section{Acknowledgements}

We thank the Australian Research Council for funding, through a Laureate Fellowship to RJH. We also thank the organizers and participants at the Novel Ecosystems special session of the inaugural SERA Conference for comments on MPP's presentation, where ideas featured in this paper were discussed. We especially thank Kris Hulvey for her willingness to share ideas featured in this manuscript and her comments on previous drafts. Finally, we appreciate the diligence and comments from two anonymous reviewers and P. Audet on a previous version of this manuscript.

\section{Received: 23 April 2013 Accepted: 5 June 2013}

\section{Published: 1 July 2013}

\section{References}

Bradshaw A (1997) Restoration of mined lands—using natural processes. Ecol Eng 8:255-269

Bradshaw CJA, Bowman DMJS, Bond NR, Murphy BP, Moore AD, Fordham DA Thackway R, Lawes MJ, McCallum H, Gregory SD, Dalal RC, Boer MM, Lynch AJ, Bradstock RA, Brook BW, Henry BK, Hunt LP, Fisher DO, Hunter D, Johnson CN, Keith DA, Lefroy EC, Penman TD, Meyer WS, Thomson JR, Thornton CM, VanDerWal J, Williams RJ, Keniger L, Specht A (2013) Brave new green world - consequences of a carbon economy for the conservation of Australian biodiversity. Biol Conserv 161:71-90

Cardinale BJ, Duffy JE, Gonzalez A, Hooper DU, Perrings C, Venail P, Narwani A, Mace GM, Tilman D, Wardle DA, Kinzig AP, Daily GC, Loreau M, Grace JB, Larigauderie A, Srivastava DS, Naeem S (2012) Biodiversity loss and its impact on humanity. Nature 486:59-67

Clewell AF, Aronson J (2013) Ecological restoration: principles, values and structure of an emerging profession, 2nd edition. Island Press, Washington D.C

Cramer VA, Hobbs RJ, Standish RJ (2008) What's new about old fields? Land abandonment and ecosystem assembly. Trends Ecol Evol 23(2):104-112

CSIRO (2007) Climate change in Australia: technical report. CSIRO. http://www. climatechangeinaustralia.gov.au/documents/resources/ TR_Web_FrontmatterExecSumm.pdf

Ellis EC (2011) Anthropogenic transformation of the terrestrial biosphere. Phil Trans R Soc A 369:1010-1035

Ellis EC, Klein Goldewijk K, Siebert S, Lightman D, Ramankutty N (2010) Anthropogenic transformation of the biomes, 1700 to 2000. Glob Ecol Biogeogr 19:589-606

Hallett LM, Standish RJ, Hulvey KB, Gardener MR, Suding KN, Starzomski BM, Murphy SD, Harris JA (2013) Towards a conceptual framework for novel ecosystems. In: Hobbs RJ, Higgs ES, Hall CM (ed) Novel ecosystems: intervening in the new ecological world order. Wiley, Chichester, pp 16-28

Halpern BS, Walbridge S, Selkoe KA, Kappel CV, Micheli F, D'Agrosa C, Bruno JF, Casey KS, Ebert C, Fox HE, Fujita R, Heinemann D, Lenihan HS, Madin EMP, Perry MT, Selig ER, Spalding M, Steneck R, Watson R (2008) A global map of human impact on marine ecosystems. Science 319:948-952

Harris JA, Hobbs RJ, Higgs E, Aronson J (2006) Ecological restoration and global climate change. Restor Ecol 14:170-176

Harris JA, Murphy SD, Nelson CR, Perring MP, Tognetti PM (2013) Characterizing novel ecosystems: challenges for measurement. In: Hobbs RJ, Higgs ES, Hall CM (ed) Novel ecosystems: intervening in the new ecological world order. Wiley, Chichester, pp 192-204

Hobbs RJ (2007) Setting effective and realistic restoration goals: key directions for research. Restor Ecol 15(2):354-357

Hobbs RJ, Norton DA (1996) Towards a conceptual framework for restoration ecology. Restor Ecol 4(2):93-110
Hobbs RJ, Arico S, Aronson J, Baron JS, Bridgewater P, Cramer VA, Epstein PR, Ewel JJ, Klink CA, Lugo AE, Norton D, Ojima D, Richardson DM, Sanderson EW, Valladares F, Vila M, Zamora R, Zobel M (2006) Novel ecosystems: theoretical and management aspects of the new ecological world order. Glob Ecol Biogeogr 15:1-7

Hobbs RJ, Higgs E, Harris JA (2009) Novel ecosystems: implications for conservation and restoration. Trends Ecol Evol 24(11):599-605

Hobbs RJ, Higgs ES, Hall CM (2013a) Defining novel ecosystems. In: Hobbs RJ, Higgs ES, Hall CM (ed) Novel ecosystems: intervening in the new ecological world order. Wiley, Chichester, pp 58-60

Hobbs RJ, Higgs ES, Hall CM (2013b) What do we know about, and what do we do about, novel ecosystems? In: Hobbs RJ, Higgs ES, Hall CM (ed) Novel ecosystems: intervening in the new ecological world order. Wiley, Chichester

Hooper DU, Chapin FS, Ewel JJ, Hector A, Inchausti P, Lavorel S, Lawton JH, Lodge DM, Loreau M, Naeem S, Schmid B, Setala H, Symstad AJ, Vandermeer J, Wardle DA (2005) Effects of biodiversity on ecosystem functioning: a consensus of current knowledge. Ecol Monogr 75(1):3-35.

Hulvey KB, Standish RJ, Hallett LM, Starzomski BM, Murphy SD, Nelson CR, Gardener MR, Kennedy PL, Seastedt TR, Suding KN (2013) Incorporating novel ecosystems into management frameworks. In: Hobbs RJ, Higgs ES, Hall CM (ed) Novel ecosystems: intervening in the new ecological world order. Wiley, Chichester

Jackson ST (2013) Perspective: ecological novelty is not new. In: Hobbs RJ, Higgs ES, Hall CM (ed) Novel ecosystems: intervening in the new ecological world order. Wiley, Chichester, pp 63-65

Jax K (2005) Function and "functioning" in ecology: what does it mean? Oikos 111(3):641-648

Kirkpatrick J, Kiernan K (2006) Natural heritage management. In: Lockwood M, Worboys GL, Kothari A (ed) Managing protected areas: a global guide. Earthscan, London, pp 421-447

Lee JA, Caporn SJM (1998) Ecological effects of atmospheric nitrogen deposition on semi-natural terrestrial ecosystems. New Phytol 139:127-134

Light A, Thompson A, Higgs ES (2013) Valuing novel ecosystems. In: Hobbs RJ, Higgs ES, Hall CM (ed) Novel ecosystems: intervening in the new ecological world order. Wiley, Chichester

Low T (2003) The new nature. Penguin, London

Mascaro J, Harris JA, Lach L, Thompson A, Perring MP, Richardson DM, Ellis E (2013) Origins of the novel ecosystems concept. In: Hobbs RJ, Higgs ES, Hall CM (ed) Novel ecosystems: intervening in the new ecological world order. Wiley, Chichester, pp 45-57

McDonnell MJ, Pickett STA (1990) Ecosystem structure and function along urban-rural gradients: an unexploited opportunity for ecology. Ecology 71 (4):1232-1237

McGill BJ, Enquist BJ, Weiher E, Westoby M (2006) Rebuilding community ecology from functional traits. Trends Ecol Evol 21(4):178-185

Millennium Ecosystem Assessment (2005) Ecosystems and human well-being: biodiversity synthesis. World Resources Institute, Washington D.C

Munro NT, Fischer J, Barrett G, Wood J, Leavesley A, Lindenmayer DB (2011) Bird's response to revegetation of different structure and floristics-are "restoration plantings" restoring bird communities? Restor Ecol 19 (201):223-235

Paul MJ, Meyer JL (2001) Streams in the urban landscape. Annu Rev Ecol Evol Syst 32:333-365

Perring MP, Ellis EC (2013) The extent of novel ecosystems: long in time and broad in space. In: Hobbs RJ, Higgs ES, Hall CM (ed) Novel ecosystems: intervening in the new ecological world order. Wiley, Chichester, pp 66-80

Perring MP, Standish RJ, Hulvey KB, Lach L, Morald TK, Parsons R, Didham RK, Hobbs RJ (2012) The Ridgefield Multiple Ecosystem Services Experiment: can restoration of former agricultural land achieve multiple outcomes? Agric Ecosyst Environ 163:14-27

Perring MP, Manning P, Hobbs RJ, Lugo AE, Ramalho C, Standish RJ (2013) Novel urban ecosystems and ecosystem services. In: Hobbs RJ, Higgs ES, Hall CM (ed) Novel ecosystems: intervening in the new ecological world order. Wiley, Chichester

Phoenix GK, Hicks WK, Cinderby S, Kuylenstierna JCl, Stock WD, Dentener FJ, Giller KE, Austin AT, Lefroy RDB, Gimeno BS, Ashmore MR, Ineson P (2006) Atmospheric nitrogen deposition in world biodiversity hotspots: the need for a greater global perspective in assessing $\mathrm{N}$ deposition impacts. Glob Chang Biol 12:470-476

Pickett STA, Cadenasso ML, Grove JM, Nilon CH, Pouyat RV, Zipperer WC, Costanza R (2001) Urban ecological systems: linking terrestrial ecological, 
physical, and socioeconomic components of metropolitan areas. Annu Rev Ecol Evol Syst 32:127-157

Prober SM, Smith FP (2009) Enhancing biodiversity persistence in intensively used agricultural landscapes: a synthesis of 30 years of research in the Western Australian wheatbelt. Agric Ecosyst Environ 132:173-191

Prober SM, Standish RJ, Wiehl G (2011) After the fence: vegetation and topsoil condition in grazed, fenced and benchmark eucalypt woodlands of fragmented agricultural landscapes. Aust J Bot 59:369-381

Pywell RF, Bullock JM, Tallowin JB, Walker KJ, Warman EA, Masters G (2007) Enhancing diversity of species poor grasslands: an experimental assessment of multiple constraints. J Appl Ecol 44:81-94

Rey-Benayas JM, Newton AC, Diaz A, Bullock JM (2009) Enhancement of biodiversity and ecosystem services by ecological restoration: a meta-analysis . Science 325:1121-1124

SERI (2006) The SER international primer on ecological restoration. SERI, Tucson, AZ

Shackelford N, Hobbs RJ, Heller NE, Hallett LM, Seastedt TR (2013) Finding a middle-ground: the native / non-native debate. Biol Conserv 158:55-62

Sherkow JS, Greely HT (2013) What if extinction is not forever? Science 340:32-33

Standish RJ, Cramer VA, Hobbs RJ, Kobryn HT (2006) Legacy of land-use evident in soils of Western Australia's wheatbelt. Plant Soil 280:189-207

Standish RJ, Cramer VA, Wild SL, Hobbs RJ (2007) Seed dispersal and recruitment limitation are barriers to native recolonization of old-fields in western Australia. J Appl Ecol 44:435-445

Standish RJ, Cramer VA, Hobbs RJ (2008) Land-use legacy and the persistence of invasive Avena barbata on abandoned farmland. J Appl Ecol 45:1576-1583

Standish RJ, Thompson A, Higgs ES, Murphy SD (2013) Concerns about novel ecosystems. In: Hobbs RJ, Higgs ES, Hall CM (ed) Novel ecosystems: intervening in the new ecological world order. Wiley, Chichester

Suding KN (2011) Towards an era of restoration in ecology: successes, failures, and opportunities ahead. Annu Rev Ecol Evol Syst 42:465-487

Tylianakis JM, Didham RK, Bascompte J, Wardle DA (2008) Global change and species interactions in terrestrial ecosystems. Ecol Lett 11:1351-1363

Vitousek PM, Aber JD, Howarth RW, Likens GE, Matson PA, Schindler DW, Schlesinger WH, Tilman DG (1997a) Human alteration of the global nitrogen cycle: sources and consequences. Ecol Appl 7(3):737-750

Vitousek PM, Mooney HA, Lubchenco J, Melillo JM (1997b) Human domination of Earth's ecosystems. Science 277:494-499

Whitham TG, DiFazio SP, Schweitzer JA, Shuster SM, Allan GJ, Bailey JK, Woolbright SA (2008) Extending genomics to natural communities and ecosystems. Science 320:492-495

Williams JW, Jackson ST (2007) Novel climates, no-analog communities, and ecological surprises. Front Ecol Environ 5(9):475-482

doi:10.1186/2192-1709-2-18

Cite this article as: Perring et al:: Incorporating novelty and novel ecosystems into restoration planning and practice in the 21 st century. Ecological Processes 2013 2:18.

\section{Submit your manuscript to a SpringerOpen ${ }^{\circ}$ journal and benefit from:}

- Convenient online submission

- Rigorous peer review

- Immediate publication on acceptance

- Open access: articles freely available online

- High visibility within the field

- Retaining the copyright to your article

Submit your next manuscript at $\gg$ springeropen.com 